\title{
Accounting
}

\section{Adaptive accounting of production activities of transnational companies under the conditions of globalization}

\author{
Kuksa Ihor $^{\mathrm{a}}$, Vasyurenko Larysa ${ }^{\mathrm{b}^{*}}$, Litvinov Anatoly ${ }^{\mathrm{c}}$, Lytvynova Olena ${ }^{\mathrm{d}}$, Shtuler Iryna ${ }^{\mathrm{e}}$, Zos-Kior \\ Mykola $^{\mathrm{f}}$ and Naholiuk Olena ${ }^{\mathrm{g}}$
}

${ }^{a}$ Head of the Department of Accounting, Finance and Information Technology, Professor, Dr. Sc. (Ekon)., Luhansk National Agrarian University, Street. Slobozhanska, 68. 92703. Starobilsk, Ukraine

${ }^{b}$ Associate Professor, Department of Accounting, Finance and Information Technology, PhD of Econ., Luhansk National Agrarian University, Street. Slobozhanska, 68. 92703. Starobilsk, Ukraine

'Professor of the Chair of Agrologistics and Supply Chain Management, Assosiate Professor, Dr. Sc. (Ekon)., Petro Vasylenko Kharkiv National Technical University of Agriculture. Alchevskih str. 44. 61002. Kharkiv. Ukraine

${ }^{d}$ Assosiate Professor of the Chair of Marketing, Entrepreneurship and Production Management, PhD of Econ., V.V. Dokuchaev Kharkiv National Agrarian University. "Dokuchaevske-2". 62483. Kharkiv region. Ukraine

${ }^{e}$ First Vice-rector, Dr. Sc. (Ekon)., Professor, National Academy of Management. Street. Ushinsky, 15. Kyiv, Ukraine

${ }^{f}$ Professor, Department of Management, Dr. Sc. (Ekon). Poltava State Agrarian Academy. Street. Skovorody, 1/3, Poltava, 36003, Ukraine

${ }^{g}$ Senior Lecturer at the Department of Management, Law, Statistics and Economic Analysis, PhD in Law, Luhansk National Agrarian University. Street. Slobozhanska, 68. 92703. Starobilsk, Ukraine

\section{H R O N I C L E}

\section{Article history:}

Received July 22020

Received in revised format July

262020

Accepted July 292020

Available online

August 22020

Keywords:

Production cost

Multinational companies

Accounting

Management

Profitability

Industry

Economy

\section{A B S T R A C T}

\begin{abstract}
In connection with the global financial and economic crisis, the leading countries have made adjustments to the economic strategies and policies to stabilize the post-crisis economy. The goal of transnationalization is, on the one hand, to reduce quickly the technological gap between domestic producers and their Western competitors, and on the other hand, to win more dynamic demand at lower costs. Ownership structure and market positioning have become two factors that determine the strategic motivation of Transnational corporations (TNCs) and the ways of their expansion. The aim of the study is to analytically generalize the globalization trends of TNCs in the field of production, taking into account industry definitions and point determination of factors influencing the effectiveness of its adaptation in industry. The profiles of adaptation of transnationalization in the sphere of production of Germany, France and the Netherlands were singled out in separate analytical sets, which allowed to reveal heterogeneity of economic practices and branch changes in the sphere of production and to determine the degree of influence of array of variables (factors): Production value and Gross operating surplus profitability of multinational companies, in the sectoral context (domestic production, ISIC Rev 4, 21 industry), as a "basket" of reserve instruments to increase the profitability of production in TNCs.
\end{abstract}

C 2020 by the authors; licensee Growing Science, Canada

\section{Introduction}

In connection with the global financial and economic crisis, the leading countries have made adjustments to the economic strategy and policies to stabilize the post-crisis economy. The international communities, unions, alliances and joint groups of countries have developed a number of joint programs to combat the crisis and its consequences. Subsequently, the problems of

* Corresponding author. Tel. +380956443821

E-mail address: vasyurenkolarysa@gmail.com (V. Larysa) 
overcoming the crisis became an integral part of the agenda of international organizations. From the point of view of the international situation, the tendencies of development of multipolarity in the world and globalization of economy are developed in a multivector way, scientific and technical progress continuously grows, more and more competition in total state power is intensifying. No country or nation can avoid such strong global competition. The world's leading economies constantly stimulate the development of advanced productive forces and defend the realization of the fundamental interests of the population.

The United Nations Conference on Trade and Development has identified a list of the 100 largest TNCs in developing countries, nine of which are Chinese trade and industry groups with a combined foreign assets of about \$54 billion. The United States employs about 80,000 people abroad. The annual ranking includes the 500 largest corporations in the world. Ownership structure and market positioning have become two factors that determine the strategic motivation of TNCs and the ways of their expansion. Depending on the type of ownership (public or private) or focus on the domestic or foreign market, we can model the strategy. There is no doubt that developed methods of doing business contribute to higher efficiency in the production of goods and services. Business development concerns two elements that are inextricably linked: the quality of the overall business in the country and the quality of individual firms, their operations and strategies. These factors are important for countries in the late stages of development, when most of the main sources of productivity gains have been exhausted. The quality of the country's business network and ancillary industries, measured by the quantity and quality of local suppliers and the degree of their interaction, is important for a number of reasons. When companies and suppliers in a particular sector are interconnected in geographically close groups, efficiency increases, there are more opportunities for innovation in the process and product creation, and barriers to entry for new firms are reduced. Complex operations and strategies of individual firms (branding, marketing, distribution of advanced technological processes, production of unique and complex goods and services) are introduced into the economy and contribute to the development of modern business processes in the country. The nature of competitive advantage expands along with the willingness to delegate authority. Previously, management within companies could be centralized, but now top management is expanding. Meanwhile the number and quality of local suppliers is declining, which may prove the displacement of small businesses by large or the influx of foreign companies into the market (Marinov et al., 2004).

\section{Research analysis and assignment}

Questions of the functioning of the industrial sector of industry, its role as a technological driver of the world economy were considered in the works of Xuan and Trung (2020), Vasyurenko and Kuksa (2020), Vertovec (2001), Sikkink (1998) and Omar and Fatah (2020). Industrial-technocratic ideas of creating transnational companies (TNCs) in today's globalization space were developed by Arnold Schuh (2012), Koupaei et al. (2016), the cyclical nature of sectoral differences and the effectiveness of TNCs were studied by Ojstersek et al. (2020). Currently, there is no single theoretical and methodological approach to reveal the directions of increasing production efficiency in the context of globalization, there is also no justification for the coexistence of TNCs and businesses at the enterprise level, which leads to disparities in technical and technological relations at most industries. Finally, there is no work to adapt transnationalization in the manufacturing sector, and much of the promising global production technologies are new to most companies, requiring adaptation to the rules of globalization.

The aim of the study is to analytically generalize the globalization trends of TNCs in the field of production, taking into account industry definitions and point determination of factors influencing the effectiveness of its adaptation in industry. The goal of transnationalization in China is, on the one hand, to reduce quickly the technological gap between domestic producers and their Western competitors, and on the other hand, to win at lower costs and more dynamic demand in China. As a rule, it all starts with the import of products produced by the company that was purchased. This allows you to analyze demand and prepare potential customers. Then the assembly is started using imported spare parts (which significantly reduces import duties), and finally, as suppliers prepare, most of the value chain is localized. Of course, this does not mean that the acquired company will stop production or sale in its markets. On the contrary, new owners usually try to maintain and expand current operations if possible. This strategy is mainly typical of mechanical engineering, but it can be found in other industries where technology is crucial and there is the possibility of moving it. Imports of product lines and similar types of acquisition of strategic assets are also common for many Chinese companies engaged in various industries. This is directly related to the advantages and disadvantages of the Chinese economy compared to its main trading partners from among developed countries: demand, much cheaper labor and lack of innovative technologies and design capabilities. Companies that invest in such strategic assets are usually private, have a manufacturing base in China and show sales growth in the domestic market. In studying the process of transnationalization of Chinese corporations, it is clear that the main role here was played by government support.

Optimization of economic development is to stimulate the development of TNCs, as a necessity in today's globalization environment, due to the entry of all sectors of the economy to medium and high levels of development, turning it into a qualitative business environment not only quantitatively but also qualitatively. It is also necessary to accelerate reforms, optimize and modernize production, through the implementation of a series of important programs to improve the technological level. 
It is necessary to strengthen the leading role of innovations, making them the main driver by the development of the country as a whole, launching new public and private scientific and technical projects, forming groups of high-level state research centers and a number of innovative enterprises, advancing innovative business activities. Analytically, we will single out and visualize a number of characteristic processes that will serve as a basis for planned adaptation, as a set of preparatory measures for further improvement of the performance process in the field of production. These processes reflect the globalization of world economic relations and determine the development of transnationalization of the economic space at a faster pace among 24 economies of the world (Figs. 1-3) :

1. Activities of international organizations. Increasing the involvement of countries in world trade organizations; intensification of the activities of international organizations aimed at the development of free trade, which does not allow member countries, without violating their commitments, to unilaterally protect their domestic markets through the introduction of import tariffs.

2. Internationalization of the production process, which is manifested in the development of transnational companies (TNCs), the involvement of almost all countries in the process of world production of goods and global value chains. The term "Made in the world" appeared.

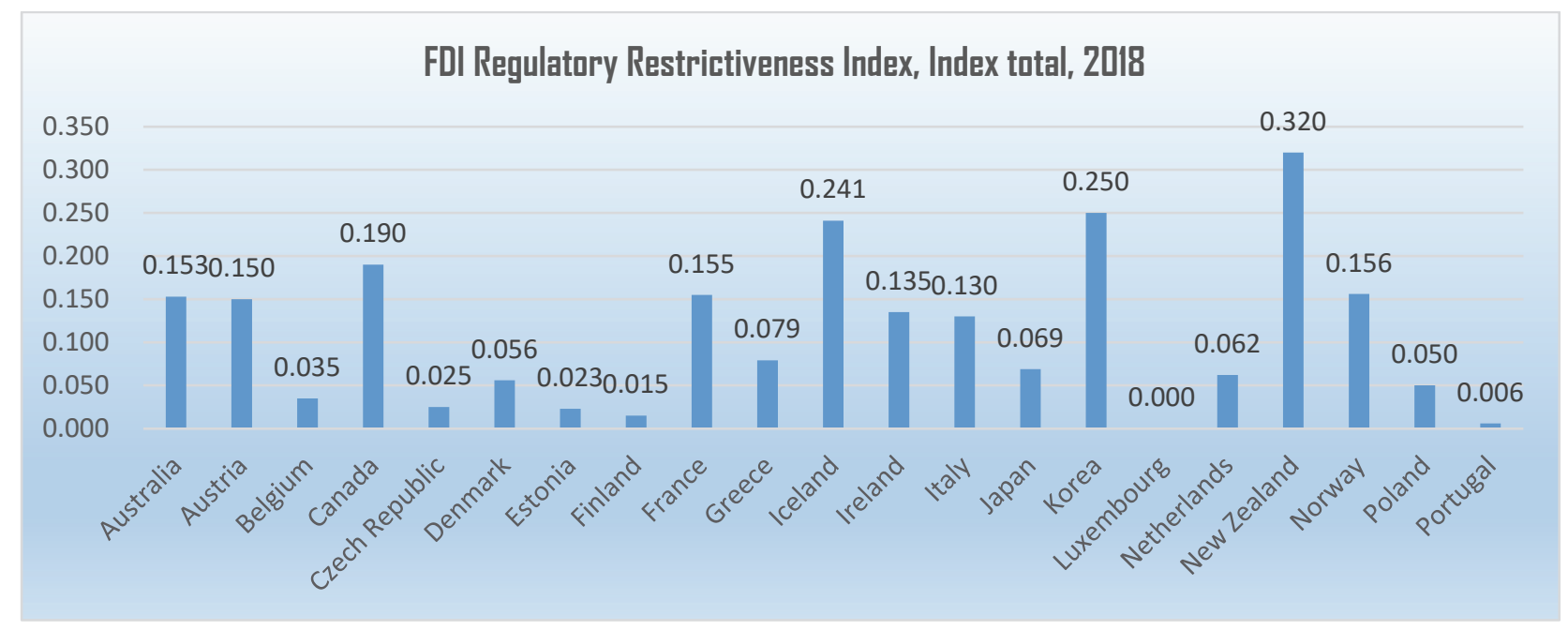

Fig.1. Total FDI index

The Index of Regulatory Restrictions on Foreign Direct Investment (Foreign Direct Investment Index) (Fig. 1) measures statutory restrictions on foreign direct investment in 22 economic sectors. It measures the limitations of foreign direct investment (FDI) rules in a country by reviewing four main types of restrictions on foreign direct investment: 1) restrictions on foreign capital; 2) mechanisms of discriminatory screening or approval; 3) restrictions on the employment of foreigners as key personnel; 4) other operational restrictions, such as restrictions on the branching and repatriation of capital or land ownership by foreign enterprises. Restrictions are rated on a scale from 0 (open) to 1 (closed). The overall indicator of limitation is the industry average. The discriminatory nature of the measures, i.e. when they are applied only to foreign investors, is the central criterion for evaluating the measure. State property and state monopolies, as long as they do not discriminate against foreigners, are not taken into account. The FDI index is not a full-fledged indicator of the investment climate in the country. There are a number of other factors at play, including how FDI rules apply. Barriers to entry may arise for other reasons, including state ownership in key sectors. The country's ability to attract FDI will be affected by other factors, such as the size of its market, the degree of its integration with its neighbors, and even geography, among others. However, foreign direct investment rules can be a decisive factor in a country's attractiveness to foreign investors. Barriers to entry may arise for other reasons, including state ownership in key sectors. The country's ability to attract FDI will be affected by other factors, such as the size of its market, the degree of its integration with its neighbors, and even geography, among others. However, foreign direct investment rules can be a decisive factor in a country's attractiveness to foreign investors (OECD, 2020). In 2014, many countries implemented the latest international standards for Foreign Direct Investment (FDI) statistics: the OECD's Benchmark Definition of FDI, 4th edition (BMD4). FDI statistics cover all parties to the relationship. The relationship with FDI is established when an investor in one country acquires $10 \%$ or more of the voting power in a business company in another country. An investor is also called a direct investor or a parent company, and a business enterprise is called a direct investment company or its subsidiary. The $10 \%$ criterion is used to establish that the direct investor has a significant degree of influence on the activities of the direct investment enterprise. 
The structure of FDI, in general, in particular, includes many projects that differ not only in scale, industry and organizational and legal structure, but also in strategic importance for the investor. In a broad sense, it is common to distinguish between the following objectives of international investment: access to new markets, access to natural resources, improving efficiency (including, in particular, increasing its scale), as well as control over strategic assets. At the macro level, these motivations are influenced by the competitive advantages and disadvantages of TNCs in a given country. At the micro level, these same factors largely depend on the source of profit (to the extent that they are understood by management), and, consequently, on the structure of a particular industry.

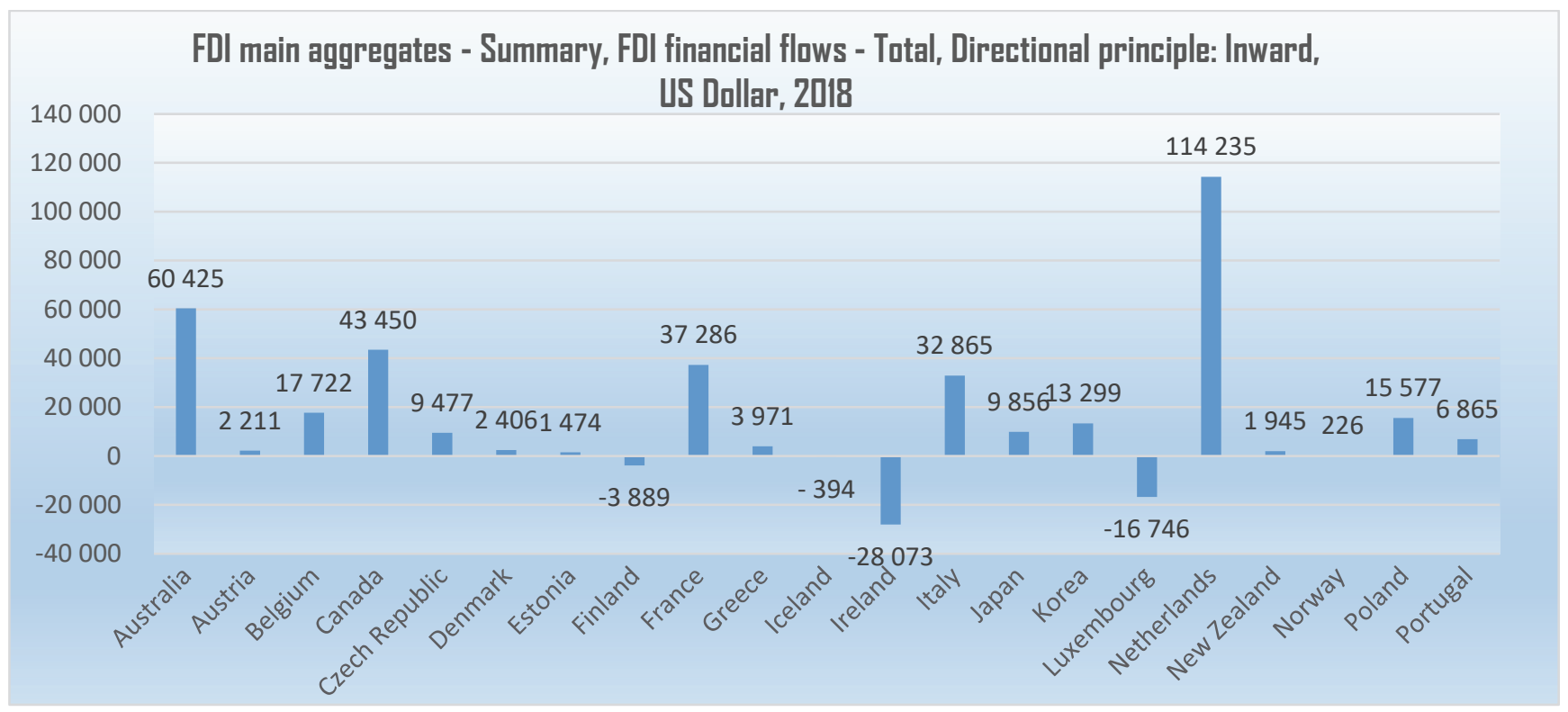

Fig. 2. FDI, Financial flows

* Source: (OECD, 2020)

FDI consumers include affiliates that are directly and indirectly owned by the parent companies. In direct ownership, it owns $10 \%$ or more of the votes. In indirect ownership, the parent controls a subsidiary, which in turn owns 10 percent or more of the electoral power of another enterprise.

\section{FDI main aggregates - Summary, Equity (excluding reinvestment of earnings), Directional principle: Inward, US Dallar, 2018}

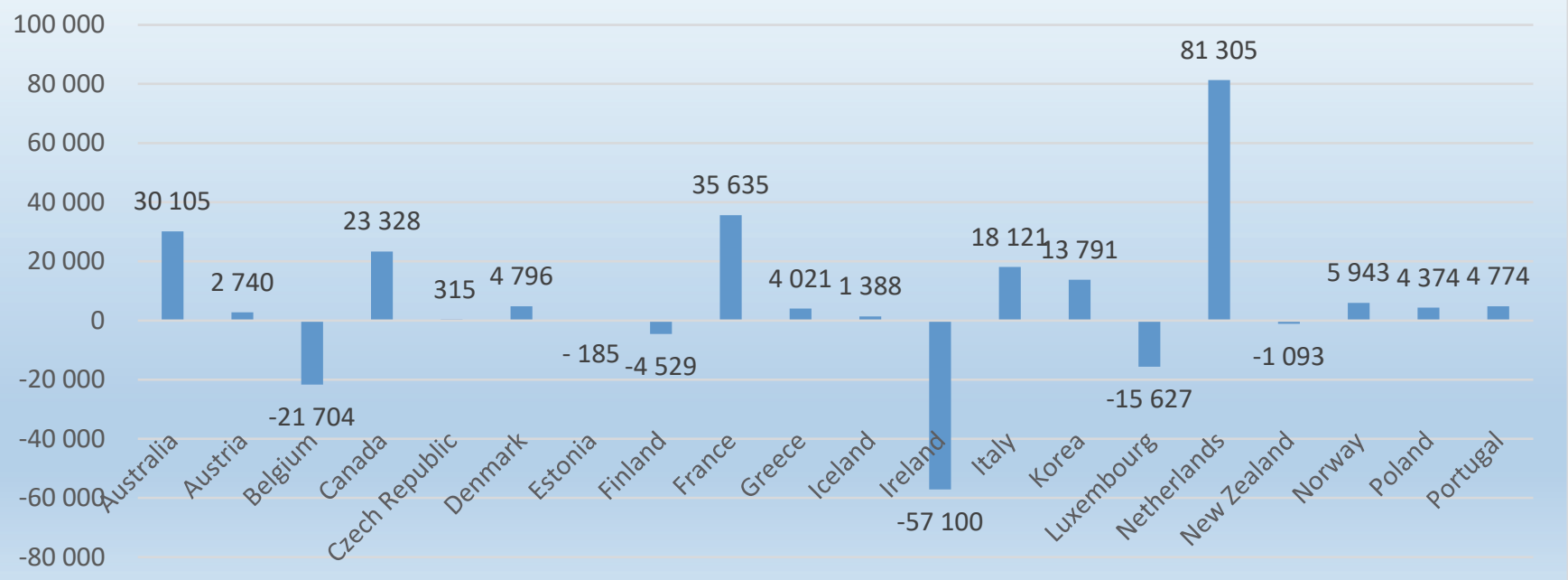

Fig. 3. FDI, Financial flows 
Consumers of foreign direct investment also include enterprises that are not in direct investment themselves, but have a common direct investor. They are called fellows because, although there is no direct investment relationship between them, any transactions between them are likely to be the result of the influence that their joint direct investor has on the joint operations.

TNCs in general (as well as their structural enterprises) are not interested in strengthening trade barriers, as the presence of barriers is associated with additional costs of production and sale of goods. In this case, TNCs, as noted in, have huge resources to lobby their own interests. It should be noted that in recent years, economists have been studying the possibility of protectionism for TNCs in the value chain, i.e. the object of protectionism itself is changing, from the protection of the national economy to the protection of TNCs - residents. The change of object entails the need for dialogue with TNC partner countries, finding solutions in foreign trade policy that maximize benefits for TNCs (Arnold Schuh, 2012). On the one hand, these statistics confirm the ongoing trend since the end of the last century to reduce the contribution of industry to the formation of world GDP and the corresponding growing dominance in its structure of services. The service sector of the economy is experiencing rapid development, increasing the attractiveness of information, financial and other service-oriented markets, in turn, manufacturing industries are less attractive to investors due to prolonged return on investment and, consequently, can not provide value added commensurate with the service sector scale. On the other hand, the products of manufacturing enterprises meet the needs of the world economy, and production remains the main component of the real sector, a source of jobs significant for any national economy high-productivity and the most important basis for taxation. One example of a new type of industrial enterprise that combines the above characteristics is General Electric's concept of a "smart plant - a single intelligent system for constructing, designing, manufacturing, supplying, distributing and servicing a product" (Weforum, 2018). Based on virtual design, production automation, digital prototyping, supply chain optimization using the industrial Internet and other modern technological solutions, the concept of "smart plant" allowed the company to gain the following benefits:

- reduction of production costs by $10-50 \%$;

- reduction of production processes time - by $20-70 \%$;

- profit growth - by $10-50 \%$;

- fivefold increase in the predictability of production processes;

- reduction in time costs for production processes by $40 \%$ (Weforum, 2018).

\section{Methods}

The initial logical basis of the contextual approach is that the selectivity of the "suitability" of specific industries for the effective existence of TNCs depends on various grounds (both general and specific) and is essentially an objective phenomenon which is to be proceeded from when studying the adaptation of the profile economic entity. "Current adaptation" is an adaptation today, in time, or as the implementation of previously planned adaptation measures, or as a forced effort of TNCs to bring their production and technological base to the level of requirements of partners, increased level of company performance. The substantive content of the contextual approach is a theoretical justification for the adaptation of elements of transnationalization, based on the private (contextual) specifics of the demand for a particular enterprise in the industry. A key role in the system of strategic planning is given to the development of options for forecasting the socio-economic development of production in the context of TNCs, which allow to assess the dynamics of GDP and budget revenues in different versions of changes in external and internal conditions. In a large set of tools used in scenario macroeconomic forecasting, a special place is occupied by intersectoral tools. Balancing properties of intersectoral models of production allow to identify imbalances in autonomous forecasts of the most important economic indicators of development and to ensure the compilation of a single system of forecast data on profitability resources and their use, balanced at the intersectoral functional level. Predictive capabilities of intersectoral models allow to solve many important analytical problems, which require a comprehensive analysis of the situation when changing certain factors-control parameters that are part of the exogenous indicators of the intersectoral model of production. The ability of this tool to assess the "sensitivity" of the economy to changes in external and internal conditions that determine the motivation of economic agents is extremely important.

\section{Results of the research}

The results of analytical action (with its proper quality) can be used to make effective management decisions. In management practice, estimates of the response of effective indicators of economic activity of the subject to changes in internal factors of influence (variables) are always required: production cost, personnel costs, number of employees, turnover, gross investment in tangible goods, intragroup exports, intragroup imports, domestic production, expanding demand of trading partners, reflected in the dynamics of final investment and consumer demand, imports and exports.

The specificity of the sample of explanatory variables for "private" performance functions is determined by the object of study - as the efficiency of TNCs in production, and the composition of "private" profitability functions, whose development the analyst efforts are aimed at, depends on the sectoral structure of the economy. industry is the most significant) and characterizes 
the current adaptation of transnationalization, which takes place in the field of production, as the implementation of previously planned adaptation measures, or as forced efforts of enterprises to approach the level of a profitable business entity

Analysis and systematization of international experience in constructing factor functions of performance allowed to compile a summary table (Tables 1-3), which used data on the activities of TNCs in Germany, France and the Netherlands, separately in terms of branches under foreign control and all firms by industry, respectively to the International Standard Industrial Classification (ISIC, version 4), where variables (factors) are grouped by industry. Thus the general variables (as a whole for internal activity of the transnational enterprises) and specific (in a branch section) are allocated. Extended reproduction in the production sphere becomes possible and occurs when an additional product is created and part of it is used for accumulation. Accumulation in industrial production is an economic process of increasing the number and improving the quality of means of production, as well as the development of the non-productive sphere.

The main source of formation of the accumulation fund is gross operating surplus, which determines the level of profitability of production. The level of profitability of the production enterprise depends on the quantity, quality and structure of sold products, gross operating surplus, production value. Thus, the analysis of these variables (factors), as well as performance indicators, the rate of expanded reproduction of capital, the level of profitability, indicates the possibilities and pace of expanded reproduction in the manufacturing sector. To study the formation of the management model of such a level of profitability, which would provide expanded reproduction on the basis of self-financing, the statistical data of the economy of France, Germany, the Netherlands were used, the current period is 2019, the base year - 2018, due to the latest data availability on the (OECD, 2020). The obtained twenty-two-factor multiple-additive model of the level of profitability has the form (Eq. (1)), the interpretation of which is given in Eq. (1),

$$
\operatorname{PPmk}(\text { ISIC Rev } 4)=\frac{\sum_{1 \ldots 21} \operatorname{Sgo}}{(\mathrm{Vp} 1+\ldots \ldots . . \mathrm{Vp} 21)},
$$

where PPmk(ISIC Rev 4) represents the level of profitability of multinational companies, respectively to the International Standard Industrial Classification (ISIC, version 4),

Sgo denotes gross operating surplus in the context of 21 branches of production,

$\mathrm{Vp}$ is the production value in the context of 21 branches of production.

In the analysis carried out by the method of chain substitution (the method allows the analysis of only two periods, therefore, taking into account the availability of data at the time of this study, the data for 2018 and 2019 were selected, Table 1,2,3). Based on these data, we calculated the influence of individual factors on the change of the performance indicator in the deterministic factor model. Comparing the values of the performance indicator before and after the change in the level of a factor allows to exclude the influence of all factors except one and to identify the influence of the latter on the growth of the performance indicator. The algorithm for calculating the model is visualized by formulas:

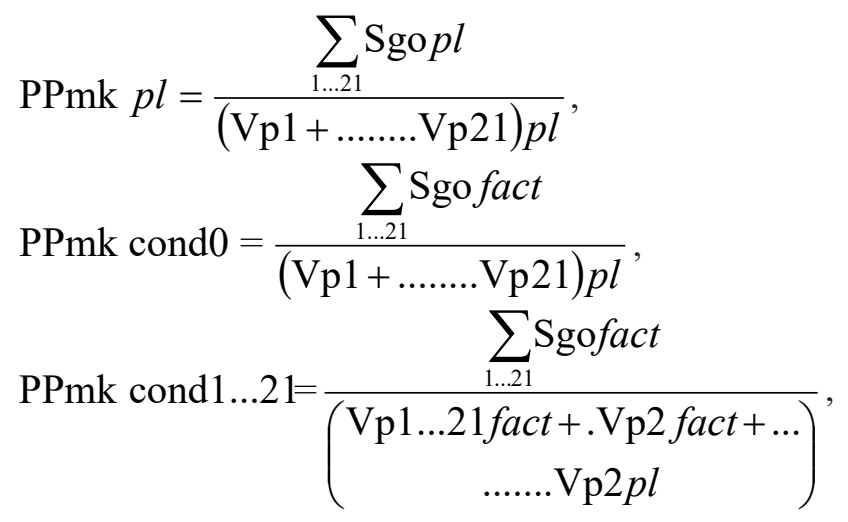

where $p l$, fact represent the indicator level in the base year (2018) and the current year (2019), respectively; cond $0 \ldots 21$ represent level of profitability due to the influence of one indicator production value from 21 industries.

Including: 
where $\Delta \mathrm{PPmk}(\mathrm{Sgo})$ represents total increase of level of profitability under the influence of Gross operating surplus; $\Delta \mathrm{PPmk}(\mathrm{Vp})$ represents total increase of level of profitability under the influence of Production value. The level of profitability depends on two main factors: gross operating surplus and production value. For a detailed analysis of the impact of the structure of production value on the level of profitability, we highlight the factors of the second level: production value in each industry (21 factors) and determine a number of conditional values of the effective indicator of profitability, which take into account changes of the first, second and the following factors. Comparison of the obtained conditional values allows to reveal the size of influence of each factor. The activity of TNCs in the field of production in France (Table 1) in the period under review shows an increase of $7.02 \%$ of total production value, while in most industries there is a decrease in production value. Negative variables (factors of influence) were the following industries where production costs increase significantly: Transport equipment by $31.46 \%$, by $10.17 \%$ - Motor vehicles, trailers and semi-trailers, by $78.71 \%$ - Other transport equipment, which reduces the level of profitability in the current period in general by $4.28 \%$ at base volumes of gross operating surplus. The general changes to the growth of volumes in the structure of gross operating surplus by industry by $11.6 \%$ stimulated to increase the level of profitability in the current period with the total value of the influence of variables at $122.75 \%$. But the negative impact of some second-level factors offset this result to $4.28 \%$. Further analysis of the results of the deterministic analysis of changes in the level of profitability in 2019 shows that a slight decrease in production costs in industries such as Wood and paper products; printing and reproduction of recorded media - by $1.45 \%$ and Paper and paper products - by $0.97 \%$ will lead to a drop in profitability by $15.08 \%$ and $26.35 \%$, respectively, in industries such as Food products, beverages and tobacco - by $0.8 \%$ will reduce profitability by $89.3 \%$. A significant reserve for the growth of the effective indicator by $9.2 \%$ is a decrease in the cost of production in the field of Textiles, wearing apparel, leather and related products by $1.02 \%$.

Table 1

France (Dataset: Inward activity of multinationals by industrial sector - ISIC Rev 4)

\begin{tabular}{|c|c|c|c|c|c|c|}
\hline \multirow[b]{2}{*}{ Indicator } & \multirow[b]{2}{*}{ Symbol } & \multicolumn{2}{|c|}{ Indicator level } & \multicolumn{2}{|c|}{ Indicators change } & \multirow{2}{*}{$\begin{array}{c}\text { Influenceof } \\
\text { factors on } \\
\text { performance, } \%\end{array}$} \\
\hline & & $\begin{array}{c}\text { base } 2018 \\
\text { year,o }\end{array}$ & $\begin{array}{c}\text { current } 2019 \\
\text { year, } 1^{2}\end{array}$ & absolute & relative, $\%$ & \\
\hline $\begin{array}{l}\text { The level of profitability of multinational } \\
\text { companies (domestic production, ISIC } \operatorname{Rev} 4 \text { ), } \\
\%\end{array}$ & $\begin{array}{l}\text { PPmk(ISIC } \\
\text { Rev 4) }\end{array}$ & 7,73 & 8,06 & - & 4,28 & 0,33 \\
\hline Gross operating surplus, Euro, Millions & Sgo & 89502,00 & 99885,00 & 10383,00 & 11,60 & 122,75 \\
\hline $\begin{array}{l}\text { Production value, Euro, Millions } \\
\text { MANUFACTURING: }\end{array}$ & $\mathrm{Vp}$ & 1157329,00 & 1238605,00 & 81276,00 & 7,02 & $-122,42$ \\
\hline Food products, beverages and tobacco & $\mathrm{Vp}_{1}$ & 178569,00 & 179998,00 & 1429,00 & 0,80 & $-89,30$ \\
\hline $\begin{array}{l}\text { Textiles, wearing apparel, leather and related } \\
\text { products }\end{array}$ & $\mathrm{Vp}_{2}$ & 19323,00 & 19125,00 & $-188,00$ & $-1,02$ & 9,20 \\
\hline $\begin{array}{l}\text { Wood and paper products; printing and } \\
\text { reproduction of recorded media }\end{array}$ & $\mathrm{Vp}_{3}$ & 36642,00 & 36112,00 & $-530,00$ & $-1,45$ & $-15,08$ \\
\hline Paper and paper products & $\mathrm{Vp}_{4}$ & 17832,00 & 17659,00 & $-173,00$ & $-0,97$ & $-26,35$ \\
\hline Printing and reproduction of recorded media & $\mathrm{Vp}_{5}$ & 8560,00 & 8129,00 & $-431,00$ & $-5,04$ & 0,71 \\
\hline $\begin{array}{l}\text { Total petroleum, chemical, rubber and plastic } \\
\text { products }\end{array}$ & $\mathrm{Vp}_{6}$ & 164699,00 & 159312,00 & $-5387,00$ & $-3,27$ & $-0,38$ \\
\hline Coke and refined petroleum products & $\mathrm{Vp}_{7}$ & 36728,00 & 32091,00 & $-4637,00$ & $-12,63$ & $-0,08$ \\
\hline Chemicals and chemical products & $\mathrm{Vp}_{8}$ & 63278,00 & 62108,00 & $-1170,00$ & $-1,85$ & 1,13 \\
\hline Pharmaceuticals & $\mathrm{Vp}_{9}$ & 35709,00 & 35750,00 & 41,00 & 0,11 & $-1,62$ \\
\hline Rubber and plastic products & $\mathrm{Vp}_{10}$ & 28984,00 & 29363,00 & 379,00 & 1,31 & 0,00 \\
\hline Other non-metallic mineral products & $\mathrm{Vp}_{11}$ & 25491,00 & 25015,00 & $-476,00$ & $-1,87$ & 0,00 \\
\hline Basic metals and fabricated metal products & $\mathrm{Vp}_{12}$ & 79346,00 & 77499,00 & $-1847,00$ & $-2,33$ & 0,01 \\
\hline Fabricated metal products & $\mathrm{Vp}_{13}$ & 52776,00 & 52714,00 & $-62,00$ & $-0,12$ & 0,00 \\
\hline Computer, electronic and optical products & $\mathrm{Vp}_{14}$ & 30597,00 & 30637,00 & 40,00 & 0,13 & 0,00 \\
\hline Electrical equipment & $\mathrm{Vp}_{15}$ & 24611,00 & 24879,00 & 268,00 & 1,09 & 0,00 \\
\hline Machinery and equipment n.e.c. & $\mathrm{Vp}_{16}$ & 42962,00 & 42913,00 & $-49,00$ & $-0,11$ & 0,00 \\
\hline Transport equipment & $\mathrm{Vp}_{17}$ & 124549,00 & 163731,00 & 39182,00 & 31,46 & $-0,29$ \\
\hline Motor vehicles, trailers and semi-trailers & $\mathrm{Vp}_{18}$ & 76549,00 & 84333,00 & 7784,00 & 10,17 & $-0,06$ \\
\hline Other transport equipment & $\mathrm{Vp}_{19}$ & 62503,00 & 111698,00 & 49195,00 & 78,71 & $-0,33$ \\
\hline Air and spacecraft and related machinery & $\mathrm{Vp}_{20}$ & $\mathbf{0 , 0 0}$ & $\mathbf{0 , 0 0}$ & 0,00 & 0,00 & 0,00 \\
\hline $\begin{array}{l}\text { Other manufacturing; repair and installation of } \\
\text { machinery and equipment }\end{array}$ & $\mathrm{Vp}_{21}$ & 48521,00 & 46429,00 & $-2092,00$ & $-4,31$ & 0,01 \\
\hline
\end{tabular}

The activities of TNCs in the field of production in Germany (Table 2) in the period under review show an increase of $1.75 \%$ of total production value, because in most industries there is at least slight increase in production value. The following industries were positive variables (impact factors) where the cost of production decreased significantly: Coke and refined petroleum products by $6.61 \%$, by $3.82 \%$ - Chemicals and chemical products, which increased the level of profitability in the current period 
by $21.93 \%$ at base volumes gross operating surplus. The general changes to the growth of volumes in the structure of gross operating surplus by industry by $24.06 \%$ stimulated to increase the level of profitability in the current period with the total value of the influence of variables at $63.03 \%$. Possible further detailing of the structure in the analysis will reveal the influence of each factor of the second level on the performance indicator. Further analysis of the results of the deterministic analysis of changes in the level of profitability in 2019 shows that insignificant changes in the growth of production costs in industries such as Wood and paper products; printing and reproduction of recorded media - by $0.57 \%$ and Paper and paper products - by $0.32 \%$ significantly affect the level of profitability and reduce it by $50.79 \%$ and $56.46 \%$, respectively. At the same time, insignificant investments in the cost of production in the industries of Textiles, wearing apparel, leather and related products - by $1.9 \%$, Food products, beverages and tobacco - by $1.08 \%$ will be a catalyst for increasing profitability by $9.94 \%$ and $37.04 \%$ respectively.

Table 2

Germany (Dataset: Inward activity of multinationals by industrial sector - ISIC Rev 4)

\begin{tabular}{|c|c|c|c|c|c|c|}
\hline \multirow[b]{2}{*}{ Indicator } & \multirow[b]{2}{*}{ Symbol } & \multicolumn{2}{|c|}{ Indicator level } & \multicolumn{2}{|c|}{ Indicators change } & \multirow{2}{*}{$\begin{array}{c}\text { Influenceof } \\
\text { factors on } \\
\text { performance, \% }\end{array}$} \\
\hline & & $\begin{array}{l}\text { base } 2018 \\
\text { year,o }\end{array}$ & $\begin{array}{c}\text { current } 2019 \\
\text { year, } 1\end{array}$ & absolute & relative, $\%$ & \\
\hline $\begin{array}{l}\text { The level of profitability of multinational } \\
\text { companies (domestic production, ISIC Rev 4), \% }\end{array}$ & $\begin{array}{l}\text { PPmk(ISIC } \\
\text { Rev 4) }\end{array}$ & 7,69 & 9,38 & - & 21,93 & 1,69 \\
\hline Gross operating surplus, Euro, Millions & Sgo & 211369,00 & 262222,00 & 50853,00 & 24,06 & 63,03 \\
\hline Production value, Euro, Millions & $\mathrm{Vp}$ & 2747613,00 & 2795632,00 & 48019,00 & 1,75 & $-61,34$ \\
\hline MANUFACTURING: & & & & & & \\
\hline Food products, beverages and tobacco & $V p_{1}$ & 198123,00 & 200258,00 & 2135,00 & 1,08 & 37,04 \\
\hline $\begin{array}{l}\text { Textiles, wearing apparel, leather and related } \\
\text { products }\end{array}$ & $\mathrm{Vp}_{2}$ & 23211,00 & 23642,00 & 431,00 & 1,95 & 9,94 \\
\hline $\begin{array}{l}\text { Wood and paper products; printing and reproduction } \\
\text { of recorded media }\end{array}$ & $\mathrm{Vp}_{3}$ & 79668,00 & 80122,00 & 454,00 & 0,57 & $-50,79$ \\
\hline Paper and paper products & $\mathrm{Vp}_{4}$ & 38001,00 & 38122,00 & 121,00 & 0,32 & $-56,46$ \\
\hline Printing and reproduction of recorded media & $\mathrm{Vp}_{5}$ & 18031,00 & 18993,00 & 962,00 & 5,34 & 0,78 \\
\hline $\begin{array}{l}\text { Total petroleum, chemical, rubber and plastic } \\
\text { products }\end{array}$ & $\mathrm{Vp}_{6}$ & 336536,00 & 331585,00 & $-4951,00$ & $-1,47$ & $-0,18$ \\
\hline Coke and refined petroleum products & $\mathrm{Vp}_{7}$ & 80311,00 & 74999,00 & $-5312,00$ & $-6,61$ & $-1,32$ \\
\hline Chemicals and chemical products & $\mathrm{Vp}_{8}$ & 133985,00 & 128863,00 & $-5122,00$ & $-3,82$ & 0,62 \\
\hline Pharmaceuticals & $\mathrm{Vp}_{9}$ & 44219,00 & 46993,00 & 2774,00 & 6,27 & $-0,77$ \\
\hline Rubber and plastic products & $\mathrm{Vp}_{10}$ & 76840,00 & 79216,00 & 2376,00 & 3,09 & $-0,01$ \\
\hline Other non-metallic mineral products & $\mathrm{Vp}_{11}$ & 43553,00 & 45306,00 & 1753,00 & 4,02 & $-0,01$ \\
\hline Basic metals and fabricated metal products & $\mathrm{Vp}_{12}$ & 220381,00 & 219475,00 & $-906,00$ & $-0,41$ & 0,00 \\
\hline Fabricated metal products & $\mathrm{Vp}_{13}$ & 123648,00 & 128846,00 & 5198,00 & 4,20 & $-0,02$ \\
\hline Computer, electronic and optical products & $\mathrm{Vp}_{14}$ & 76483,00 & 81305,00 & 4822,00 & 6,30 & $-0,02$ \\
\hline Electrical equipment & $\mathrm{Vp}_{15}$ & 100054,00 & 101630,00 & 1576,00 & 1,58 & $-0,01$ \\
\hline Machinery and equipment n.e.c. & $\mathrm{Vp}_{16}$ & 238787,00 & 245463,00 & 6676,00 & 2,80 & $-0,02$ \\
\hline Transport equipment & $\mathrm{Vp}_{17}$ & 413878,00 & 429189,00 & 15311,00 & 3,70 & $-0,05$ \\
\hline Motor vehicles, trailers and semi-trailers & $\mathrm{Vp}_{18}$ & 370792,00 & 384016,00 & 13224,00 & 3,57 & $-0,04$ \\
\hline Other transport equipment & $\mathrm{Vp}_{19}$ & 43087,00 & 45173,00 & 2086,00 & 4,84 & $-0,01$ \\
\hline Air and spacecraft and related machinery & $\mathrm{Vp}_{20}$ & $\mathbf{0 , 0 0}$ & $\mathbf{0 , 0 0}$ & 0,00 & 0,00 & 0,00 \\
\hline $\begin{array}{l}\text { Other manufacturing; repair and installation of } \\
\text { machinery and equipment }\end{array}$ & $\mathrm{Vp}_{21}$ & 89125,00 & 93536,00 & 4411,00 & 4,95 & $-0,01$ \\
\hline
\end{tabular}

* Source: (OECD, 2020)

The activity of TNCs in the field of production in the Netherlands (Table 3) shows in the period under review a decrease of $1.46 \%$ of total production value, while in most industries there is an increase in production value: Electrical equipment by $8.3 \%$, by $10.46 \%$ - Motor vehicles, trailers and semi-trailers, at $11.23 \%$ - Pharmaceuticals. The following industries were positive variables (impact factors) where the cost of production decreased significantly: Coke and refined petroleum products - by $22.4 \%$, Other transport equipment - by $13.23 \%$, which increases the level of profitability in the current period by $12.18 \%$ at base volumes gross operating surplus. The general changes to the growth of volumes in the structure of gross operating surplus by industry by $12.18 \%$ stimulated the increase of the level of profitability in the current period with the total value of the influence of variables at $365.65 \%$. But the negative impact of some second-level factors offset this result to $1.24 \%$. Further analysis of the results of the deterministic analysis of changes in the level of profitability in 2019 shows that a slight increase in production costs in industries such as Food products, beverages and tobacco - by $4.6 \%$ will reduce profitability by $323.1 \%$; Wood and paper products; printing and reproduction of recorded media - by $3.03 \%$ and Paper and paper products - by $1.63 \%$ will lead to a drop in profitability by $14.62 \%$ and $30.41 \%$, respectively. The reserve for the growth of the effective indicator by $2.06 \%$ is a decrease in the cost of production in the field of Chemicals and chemical products by $5.8 \%$. 
Table 3

Netherlands (Dataset: Inward activity of multinationals by industrial sector - ISIC Rev 4)

\begin{tabular}{|c|c|c|c|c|c|c|}
\hline \multirow[b]{2}{*}{ Indicator } & \multirow[b]{2}{*}{ Symbol } & \multicolumn{2}{|c|}{ Indicator level } & \multicolumn{2}{|c|}{ Indicators change } & \multirow{2}{*}{$\begin{array}{c}\text { Influenceof } \\
\text { factors on } \\
\text { performance, } \%\end{array}$} \\
\hline & & $\begin{array}{l}\text { base } 2018 \\
\text { year,o }\end{array}$ & $\begin{array}{l}\text { current } 2019 \\
\text { year, }, 1\end{array}$ & absolute & relative, $\%$ & \\
\hline $\begin{array}{l}\text { The level of profitability of multinational } \\
\text { companies (domestic production, ISIC Rev 4), \% }\end{array}$ & $\begin{array}{l}\text { PPmk(ISIC } \\
\text { Rev 4) }\end{array}$ & 8,94 & 10,18 & - & 13,84 & 1,24 \\
\hline Gross operating surplus, Euro, Millions & Sgo & 40112,00 & 44996,00 & 4884,00 & 12,18 & 365,65 \\
\hline Production value, Euro, Millions & $V p$ & 448575,00 & 442018,00 & $-6557,00$ & $-1,46$ & $-364,41$ \\
\hline MANUFACTURING: & & & & & & \\
\hline Food products, beverages and tobacco & $\mathrm{Vp}_{1}$ & 74111,00 & 77522,00 & 3411,00 & 4,60 & $-323,10$ \\
\hline Textiles, wearing apparel, leather and related products & $\mathrm{Vp}_{2}$ & 3388,00 & $\mathbf{3 4 8 6 , 0 0}$ & 98,00 & 2,89 & 4,05 \\
\hline $\begin{array}{l}\text { Wood and paper products; printing and reproduction } \\
\text { of recorded media }\end{array}$ & $\mathrm{Vp}_{3}$ & 13589,00 & 14001,00 & 412,00 & 3,03 & $-14,62$ \\
\hline Paper and paper products & $\mathrm{Vp}_{4}$ & 7012,00 & 7126,00 & 114,00 & 1,63 & $-30,41$ \\
\hline Printing and reproduction of recorded media & $\mathrm{Vp}_{5}$ & 3566,00 & 3497,00 & $-69,00$ & $-1,93$ & $-0,16$ \\
\hline $\begin{array}{l}\text { Total petroleum, chemical, rubber and plastic } \\
\text { products }\end{array}$ & $\mathrm{Vp}_{6}$ & 82340,00 & 74849,00 & $-7491,00$ & $-9,10$ & 0,04 \\
\hline Coke and refined petroleum products & $\mathrm{Vp}_{7}$ & 26921,00 & 20891,00 & $-6030,00$ & $-22,40$ & 0,09 \\
\hline Chemicals and chemical products & $\mathrm{Vp}_{8}$ & 48963,00 & 46123,00 & $-2840,00$ & $-5,80$ & 2,06 \\
\hline Pharmaceuticals & $\mathrm{Vp}_{9}$ & 7008,00 & 7795,00 & 787,00 & 11,23 & $-2,25$ \\
\hline Rubber and plastic products & $\mathrm{Vp}_{10}$ & 8291,00 & 8718,00 & 427,00 & 5,15 & $-0,01$ \\
\hline Other non-metallic mineral products & $\mathrm{Vp}_{11}$ & 5088,00 & 5381,00 & 293,00 & 5,76 & $-0,01$ \\
\hline Basic metals and fabricated metal products & $\mathrm{Vp}_{12}$ & 25731,00 & 27457,00 & 1726,00 & 6,71 & $-0,04$ \\
\hline Fabricated metal products & $\mathrm{Vp}_{13}$ & 18724,00 & 20037,00 & 1313,00 & 7,01 & $-0,03$ \\
\hline Computer, electronic and optical products & $\mathrm{Vp}_{14}$ & 36823,00 & 36169,00 & $-654,00$ & $-1,78$ & 0,02 \\
\hline Electrical equipment & $\mathrm{Vp}_{15}$ & 7481,00 & 8102,00 & 621,00 & 8,30 & $-0,01$ \\
\hline Machinery and equipment n.e.c. & $\mathrm{Vp}_{16}$ & 24743,00 & 25825,00 & 1082,00 & 4,37 & $-0,03$ \\
\hline Transport equipment & $\mathrm{Vp}_{17}$ & 17999,00 & 18066,00 & 67,00 & 0,37 & 0,00 \\
\hline Motor vehicles, trailers and semi-trailers & $\mathrm{Vp}_{18}$ & 12012,00 & 13269,00 & 1257,00 & 10,46 & $-0,03$ \\
\hline Other transport equipment & $\mathrm{Vp}_{19}$ & 9856,00 & 8552,00 & $-1304,00$ & $-13,23$ & 0,03 \\
\hline Air and spacecraft and related machinery & $\mathrm{Vp}_{20}$ & $\mathbf{0 , 0 0}$ & 0,00 & 0,00 & 0,00 & 0,00 \\
\hline $\begin{array}{l}\text { Other manufacturing; repair and installation of } \\
\text { machinery and equipment }\end{array}$ & $\mathrm{Vp}_{21}$ & 14929,00 & 15152,00 & 223,00 & 1,49 & $-0,01$ \\
\hline
\end{tabular}

Table 4

Solving the model of the level of profitability of TNC production in France, Germany, the Netherlands by economic sectors *

\begin{tabular}{|c|c|c|c|c|c|c|c|c|}
\hline \multicolumn{2}{|c|}{$\begin{array}{l}\text { France: The level of } \\
\text { performance indicator, } \\
\text { PPmk(ISIC Rev 4) }\end{array}$} & \multirow[t]{2}{*}{$\begin{array}{c}\text { Increase of } \\
\text { performance } \\
\text { indicator, } \\
\Delta \text { PPmk(ISIC } \\
\text { Rev 4) } \\
122,75\end{array}$} & \multicolumn{2}{|c|}{$\begin{array}{l}\text { Germany: The level of } \\
\text { performance indicator, } \\
\text { PPmk(ISIC Rev 4) }\end{array}$} & \multirow[t]{2}{*}{$\begin{array}{c}\text { Increase of } \\
\text { performance } \\
\text { indicator, } \\
\Delta \text { PPmk(ISIC } \\
\text { Rev 4) } \\
\mathbf{6 3 , 0 3}\end{array}$} & \multicolumn{2}{|c|}{$\begin{array}{l}\text { Netherlands: The level of } \\
\text { performance indicator, } \\
\text { PPmk(ISIC Rev 4) }\end{array}$} & \multirow[t]{2}{*}{$\begin{array}{c}\text { Increase of } \\
\text { performance } \\
\text { indicator, } \\
\Delta \text { PPmk(ISIC } \\
\text { Rev 4) } \\
\mathbf{3 6 5 , 6 5}\end{array}$} \\
\hline Base year & 7,73 & & Base year & 7,69 & & Base year & 8,94 & \\
\hline Condition 1 & 130,49 & $-89,30$ & Condition 1 & 70,72 & 37,04 & Condition 1 & 374,59 & $-323,10$ \\
\hline Condition 2 & 41,19 & 9,20 & Condition 2 & 107,76 & 9,94 & Condition 2 & 51,50 & 4,05 \\
\hline Condition 3 & 50,39 & $-15,08$ & Condition 3 & 117,69 & $-50,81$ & Condition 3 & 55,55 & $-14,62$ \\
\hline Condition 4 & 35,31 & $-26,35$ & Condition 4 & 66,89 & $-56,45$ & Condition 4 & 40,93 & $-30,41$ \\
\hline Condition 5 & 8,96 & 0,71 & Condition 5 & 10,44 & 0,78 & Condition 5 & 10,52 & $-0,16$ \\
\hline Condition 6 & 9,67 & $-0,38$ & Condition 6 & 11,22 & $-0,18$ & Condition 6 & 10,35 & 0,04 \\
\hline Condition 7 & 9,29 & $-0,08$ & Condition 7 & 11,04 & $-1,32$ & Condition 7 & 10,39 & 0,09 \\
\hline Condition 8 & 9,21 & 1,13 & Condition 8 & 9,72 & 0,62 & Condition 8 & 10,48 & 2,06 \\
\hline Condition 9 & 10,34 & $-1,62$ & Condition 9 & 10,34 & $-0,77$ & Condition 9 & 12,55 & $-2,25$ \\
\hline Condition 10 & 8,71 & 0,00 & Condition 10 & 9,57 & $-0,01$ & Condition 10 & 10,30 & $-0,01$ \\
\hline Condition 11 & 8,71 & 0,00 & Condition 11 & 9,56 & $-0,01$ & Condition 11 & 10,29 & $-0,01$ \\
\hline Condition 12 & 8,71 & 0,01 & Condition 12 & 9,56 & 0,00 & Condition 12 & 10,28 & $-0,04$ \\
\hline Condition 13 & 8,73 & 0,00 & Condition 13 & 9,56 & $-0,02$ & Condition 13 & 10,24 & $-0,03$ \\
\hline Condition 14 & 8,73 & 0,00 & Condition 14 & 9,54 & $-0,02$ & Condition 14 & 10,21 & 0,02 \\
\hline Condition 15 & 8,73 & 0,00 & Condition 15 & 9,53 & $-0,01$ & Condition 15 & 10,22 & $-0,01$ \\
\hline Condition 16 & 8,73 & 0,00 & Condition 16 & 9,52 & $-0,02$ & Condition 16 & 10,21 & $-0,03$ \\
\hline Condition 17 & 8,73 & $-0,29$ & Condition 17 & 9,50 & $-0,05$ & Condition 17 & 10,19 & 0,00 \\
\hline Condition 18 & 8,44 & $-0,06$ & Condition 18 & 9,45 & $-0,04$ & Condition 18 & 10,18 & $-0,03$ \\
\hline Condition19 & 8,38 & $-0,33$ & Condition19 & 9,40 & $-0,01$ & Condition19 & 10,15 & 0,03 \\
\hline Condition 20 & 8,05 & 0,00 & Condition 20 & 9,39 & 0,00 & Condition 20 & 10,18 & 0,00 \\
\hline Condition 21 & 8,05 & 0,01 & Condition 21 & 9,39 & $-0,01$ & Condition 21 & 10,18 & $-0,01$ \\
\hline Current year & 8,06 & $\mathbf{0 , 3 3}$ & Current year & 9,38 & 1,69 & Current year & 10,18 & 1,24 \\
\hline
\end{tabular}

* Source: own development 
The general prospects for further growth of profitability of TNC production in the studied countries in the field of development in the medium term are positive. Although there are several reasons for concern in the industry context. There are serious general imbalances in the production of countries, in particular analytically identified areas of significant impact on performance: Wood and paper products; printing and reproduction of recorded media, Paper and paper products, Textiles, wearing apparel, leather and related products, Food products, beverages and tobacco, which require special attention when planning and forecasting the production of these companies. There is an excess production capacity globally in labor-intensive industries, and in the number of capital-intensive products. Thus, from the presented information on the development of TNCs, it is possible to confirm the theory of competitiveness of countries where the main engine is national companies. The fact that the main sectors for the development of TNCs are export-oriented sectors, once again confirms the need for government support for exports. The flow of FDI due to the active activities of TNCs abroad, promotes the development of the innovation sector, increasing the technological readiness of enterprises, improving production processes and, consequently, the quality of products, ensuring competitiveness in both domestic and foreign markets. There is a need to regulate the involvement of FDI in terms of their sectoral orientation, compliance with international standards in order to create an innovative component for research in the framework of the country's integration into global value chains.

\section{Conclusions}

The specifics of the current development of world production concentrated in TNCs were analytically summarized, noting a number of characteristic processes that will serve as a basis for planned adaptation, as a set of preparatory measures to further improve the process of efficiency in production. The contextual approach to the adaptation of TNCs in the field of production in terms of industry classification (ISIC Rev 4) was substantiated as a theoretical justification for the adaptation of elements of transnationalization, based on the private (contextual) specifics of a particular enterprise in the industry. The profiles of separate economic environments (France, Germany, the Netherlands) with the existence of TNCs (in terms of individual countries) are studied and reserves of adaptation for growth of production profitability with point reaction in each separate branch are revealed. In the study of the formation of the management model of TNCs of such a level of profitability, which would provide expanded reproduction on the basis of self-financing, statistical reporting data were used. It is proposed to apply the deterministic analysis of the constructed factor model of the level of profitability. With significant changes in the values of the constituent factors of the model, it allows to identify the most influential factors, and hence - reserves to improve management efficiency, especially profitability, neutralize negative trends and identify reserves for efficiency.

\section{References}

Marinov, M. A., Marinova, S. T., \& Morita, K. (2004). Internationalization of Japanese multinational corporations in Central and Eastern Europe. Journal of East-West Business, 9(3-4), 27-52.

Koupaei, M. N., Mohammadi, M., \& Naderi, B. (2016). An integrated enterprise resources planning (ERP) framework for flexible manufacturing systems using business intelligence (BI) tools. International Journal of Supply and Operations Management, 3(1), 1112.

Organisation for Economic Co-operation and Development. https://stats.oecd.org/

Ojstersek, R., Brezocnik, M \& Buchmeister, B. (2020). Multi-purpose optimization of production planning using evolutionary computing: an overview. International Journal of Industrial Engineering computions, 11(3), 359-376.

Omar, Z \& Fatah, F. (2020). Unravelling the factors affecting agriculture profitability enterprise: Evidence from coconut smallholder production. Accounting, 6(4), 493-500.

Readiness for the Future of Production Assessment 2018 edition/ World Economic Forum.

Schuh, A. (2012). Strategy review for Central and Eastern Europe: Strategic responses of foreign multinational corporations to the recent economic and financial crisis. Journal of East-West Business, 18(3), 185-207.

Sikkink, K. (1998). Transnational politics, international relations theory, and human rights. PS: Political Science and Politics, 31(3), 516523.

Vasyurenko, L., Kuksa, I., \& Danylenko, V. (2019). Ordering Logistics Management of Professional Standard Attribution of the Higher Education Specialist. International Journal of Supply and Operations Management, 6(4), 389-394.

Vasyurenko, L., Kuksa, I., Danylenko, V., \& Wang Jing (2020). A compendium of globalization trends in world trade: Justification of a twotire model of business processes. Accounting, 6(4), 501-508.

Vertovec, S. (2001). Transnationalism and identity. Journal of Ethnic and Migration studies, 27(4), 573-582.

Xuan, V., \& Trung, N. (2020). Factors affecting quality management in business: Evidence in Vietnam manufacturing and technology enterprises. Management Science Letters, 10(9), 2099-2106.

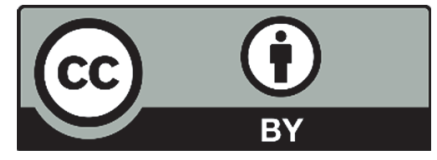

(C) 2020 by the authors; licensee Growing Science, Canada. This is an open access article distributed under the terms and conditions of the Creative Commons Attribution (CC-BY) license (http://creativecommons.org/licenses/by/4.0/). 